\title{
先秦・両漢の “見”について
}

\author{
小方 伴子

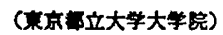

古汉语中存在着两种「“见”十动词」结构 (以下「“见”十动词」)，一种用于受 事主语句, 即通常所说的被动式, 另一种用于施事主语句, 即所谓的主动「“见”+ 动词」。由于主动「“见”十动词」有诸多解释，因而亦引起对被动「“见”十动词」 的论争。

本稍作为研究两种「“见"+动词」的第一阶段, 纵观了先秦两汉的被动「“见” 十动词」的特儌和演变过程, 得出如下结论:

(1)先秦两汉的 「“见”，动词」有三个特徽 : 第一，动词的半数以上是情态动词或人 事动词 : 第二, 动词所表现的动作行为、心理活动都给主语带来某种得失 : 第三, 主语大多限于人或者与人有密切关系的亭物。

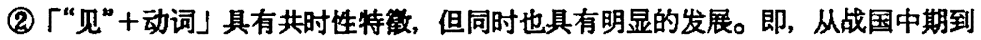
东汉，此式的动词种类、用例数旦都有大量增加。因此可以说，在此期间「“见”+ 动词」仍然不断产生新句, “兄”也逐演变成为一个表示被动的语法记号。

1. はじめに

2. “見”の媵につく功嗣の制限

3. “見” の特徽と変退

\section{1. 特徵}

1. はじめに

下の(1)(2)は马1898が被動をあらわす “見” の例として挙げるすのである。

（1）百姓之不見保，爲不用恩焉。（孟子·梁惠 王上)

（人民が保んぜられないのは、［王か］恩 を注どこさないためである）

（2）漠已破矣，齊趣下三圆，不且晃居。（史 記・齊悼惠世家)

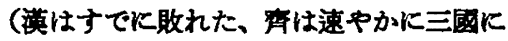
下れ、さむなくばやられるだろらく

（3）然而望主不加誅, 宰臣不見斥, 非其幸锹

!（朝愈・進學解）

(しかし聖主は誅せず、害臣は排斥しなか

\section{2. 変退}

3.3. 被動形式「“見”+動詞」の成立 4. まとめ
った、幸せなことではないか!)

马1898はこのような例をいくつか釈介した あと、施京を主語にもつ(3)を举げ、「その意

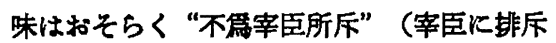
されない”であろらが、そらすると “見斥” の二字は反対に用いられていることになる。 わからないうと述へ、後に課題を残した。

この課題に対し杨1931は、施事を主語に。

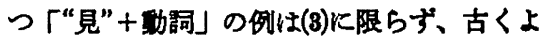
り存在するとして、(4)(5)を举げる。

（4）葬長子字，非葬鬲紦衛氏，恐需長大後見 忽。(漢書・云䑤傳)

（莽の長男の宇は、葬が衛氏を遠ざけてい るのを非難し、帝が成長した後、怨むので 
はないかと恐れた）

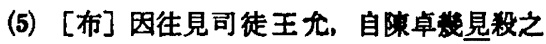
狀。(後漠毒・呂布傳)

（[布］はそこで司徒王允に会いに行き、 卓が [自分]をすら少しで殺すところだっ た状況を陳べた）

杨1931は、こらした“見”を「(被䡃の“見” の）変法」であると説く。「被偊の変法」と は、受索が潜在化している被娌を意味してい ろ"。

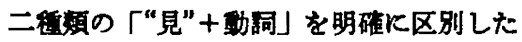
のは吕1943で、(1)(2)の「“見”+缜詞」は被動 をあらわすか、、(8)の「“見”十䡃詞」の“見” は、動詞の後に一人称代詞が省略されている ことをしめすとする。(6)は吕1943が、(3)に頼 する例として挙げるすのである。

（6）若使君不見聽許，登亦未敢禩使君也。 （三國志・蜀萻・先主你）

（もし長官殿がお间きとどけにならないな ら、登もまた長官股には従らわけにはまい りませぬ)

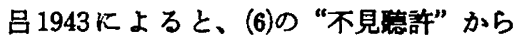
“見”をとり、“复許”のあとに一人称代詞 “我”、具体的には “登”をつけて “不垶許 登”としてる、文意はまったく变らない。

施事を主語にもつ「“見”十䡃詞」の“見”、 いわゆる主栜の “見”が一人称代詞の意味・ 機能をむつとい5説は、長く定説とされてき たが、近年、王晖1986、姚1988Kよって反論 が出された。両者は一人称代詞説を否定する 根拋として、「“見”+䡃詞」の後に㭪い5 定語は一人称に限らないことを兴げ、さらに 主娌の “見” は先莱から存在すると述べる。 (フ)(8)は姚1988が举げる早期の主野の“見”の 例である。

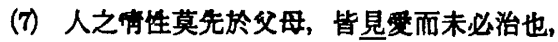
（韩非子・五等)"

(人の情は父母の采にまさるものはない、 [父母は子供たちを］要するが、かならず しもらまく治まるとは限らず，〜）
（8）京人以王子第子任、欲子之厚之、無所 見䶍。(戰国策・趋策二)

（わたしは王子をあなたに任せます。あな たが彼を深く要し、䍀をことのないよう望 みます)

主動の“見”の意味解积は両者で異なる。 王晖1986は“見”を施受同辞とみなし、被動 の合は “这遇”、能娌の㙛合は“施加”の 意味をあらわすとする。一方姚1988は、主動 の“見”は“顆示”の意味をあらわし、「“見” 十野詞」は全体が単一轩詞の機能をすつとす る。な秛䡃の“見”は王晖1986と同じく、

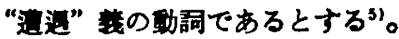

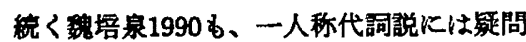
を旺している。たたし主轩の“見”は、渎代 の樈々な語法変化の中から生まれたとし、先 秦より存在するといら王晖1986説を否定して いる"'。

刘1995 万一人代代説を否定するが、王轫 1986、姚1988、魏培泉1990とは異なり、主禹

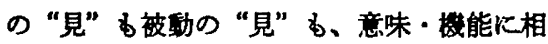
違はなく、「“見”十禹詞」が能轩・被䖝の両

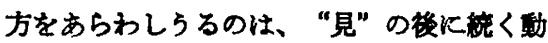
詞自体が能動・被娌の両義を担うことによる とする。

このよらK、主功の“見”の解积はいます って据れており、それが被功の“見”をむ巻 き込んだ袷争を引き起こしている。

二種類の “見”の闺俰を知るには、それぞ れの特钽・变䙴を詳しく調べる必要がある。 そのひとつの切り口として、“見” の喰につ く功詞に焦点を当てるといら方法が考えられ る。すなわち主场の “見”之被功の “見”の

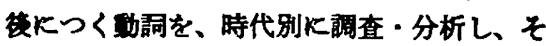
の結果を対照することにより両者の咸係を考 察しようという試みである。本和では、その 試みの第一段階として、先秦・両潢の被韧の “見”を対象とした調査・分析を行う。

なお 2 節以降の“見”は、特に指揞がな子 れば被㢦の“見”を指す。 


\section{2. “見”の後につく娌詞の制限}

“被”の喰につく動詞には、古くは“被”の 本善飞基つく制限があったとされる”。“鳥” を用いた被㲜表現も、先秦・西漠においては、 限られた動詞にしか用いられなかっだ。

ところが“見”に成しては、後につく動詞 の制限に触れた記速は見当たらない。“見” は後につく動詞に制限がなく、「・される」 といら菠動善を自由に担いらるるのだったの だろらか。

被動の “見”の渎につく動詞に制限がある ならば、それは「“見”十動詞」の意味・機能 を反映していることになり、主偊の“見”と の成係を考察する上でも重要なポイントとな りらる。

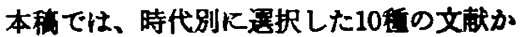
ら被動の意味をあらわす「“見”十動詞」を娭 出し、後比つく動詞を分類・分析する。

検出に当たっては、個々の用例の “見”が

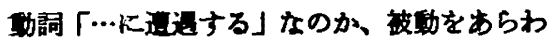
す助轩詞「…される」なのかは問題としない。

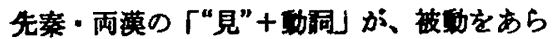
わす形式として硣立していたか否かは、むし ろ取拾した用例を分析していく遗程で明らか 飞なっていくのではないかと考える。

動詞の分類は本1994K基づき、下記のよう k行引"。

\section{[動詞の分頼}

A. 抽象功司

A-1 感知動詞：感知・思惟・言语飞盟 わる行為・活動をあらわす “的”“思”“言”...

A-2 倩態动詞：偖粕・熙度・思虑・意 图闺わる行為・活轵をあらわす

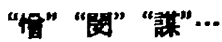

B. 具体動詞

B-1 人事動詞：人と人との間飞存在す る行為・活動をあらわす
“殺”“伐”“嫁”...

B-2 支配轵同：物や人に対して支配的 作用をはたす行為をあらわす “来”“救”“投”...

B-3 䍖予動詞：閶係する双方の間得 失が存在する行為をあらわす “賜” “集” “取”...

C. 状態䵢铝

$$
\text { “荒”“娍”“興”... }
$$

なお “受（祱を受け入れる）“從（䂱に従 5)”のよ5K、本来は具体動詞たか、抽象 的な意味で使われているるのに恃四角括弧を つけて [“受（説を受け入れる）”［“從（説 に徒5)”] と表示する。

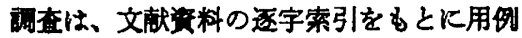
を検出し、それを位頼できる校打本で礁認す るといら方法で行ら。

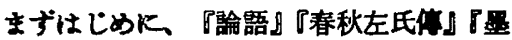
子』『孟子』『菲子』の 5 文献を戦国中期まて の調査資料として报い、全篇から被動の意味 をあらわす「“見”十動詞」の用例を榙出する。 結果は以下の通りで、“見”の後につく動詞 は、感知動詞・情態動詞・人束勳詞に限られ る。

\section{A. 抽象動鹖}

A-1 感知嗭泀 “㩆 (みなす)"

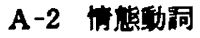

“惡（にくむ）“舟”“侮” “屡” “笑”“硫”

B. 具体動詞

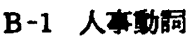 “㹲”“伐”“保(やすんしる)”“剖 心”

“見” の後につく動詞怔、国中期以前の 5 文献では、大半が情㤵動詞と人事動詞であ る。(9)《情態動詞 “惡”、(10)次人事動詞 “伐” 
の例を誉げる。

（9）年四十而見惡㻕，其䊀也已。（論語 - 陽 货)

（四十歳になっても悄まれるよらでは、お しまいだろら)

(10）随之見代，不量力也。（春秋左氏傅・俻 公20年）

（院が伐たれたのは、実力を考えなかった からだ)

なお検出した用例を文全体から覞察すると、 「“見”十動詞」の主覀は、戦国中期以前の 5 文献では、上の他が国である以外はすべて人 である。

次飞『苗子』『暲非子』『吕氏春秋』の3 文 献を戦国末期の調查凘料とし、同様の検出を 行5。“見”の後につく動詞任、戦国中期以

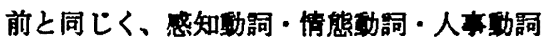
には注限られる。たたしとれらに属する䡃詞

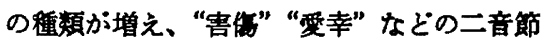
動詞も現れている。

A. 抽象動詞

A-1 感知動詞

“調（みなす）“以雹”“忘”

“德（㯖き入れる)”“置”

A-2 倩態動詞

“惡（にくむ）“爱”“要敬”“爱 幸”“㑮”“活（名誉を提なら）”

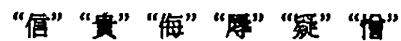

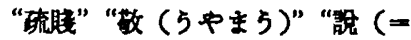
“誢”)"

B. 具体動詞

\section{B-1 人本趿詞}

“传”“客伤”“部”“剖心”“般”

“刑”“和”“却”“传”

“由”(=“用”，重用する)、閉(仕 官の途を閉ざす、重用しない)

B-2 睗予動詞

[“受（説を受け入れる）”]
下の(1)1)(13)は、戦国中期以前の調查資料に はみられなかった「“見”十二音節動詞」の例 である。

(11) 凡人之動也，爲赏度爲之則見害偣焉止矣。 （苟子・翌兵）

（凡そ人が行功をする场合、赏度のために なナのであれば、损害を受ければやめる）

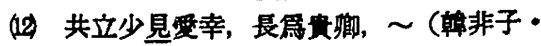
内僻説下六微)

（共立は若いころは可爱からられ、長しててか らは位の高い役人となり〜)

（敬人者，己也；見敬爱者，人也。

（呂氏春欧・必己）

（敬し受するのは自分であり、草敬され 要されるのは人である)

戦国末期の「“見”+動詞」においては、戦 国中期以菂と同しょらK、主語はほとんど人

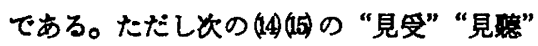
の主語には、「説」を意味する語が想定され る。

(44) 以至智說至型末必至而見受，～（韓非子 - 難言)

（至智が至望に進旾するのでさえ、会って すぐ的されれられるとは限らない、〜

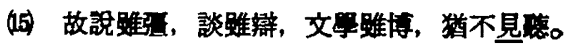
（呂氏春秋・荡兵）

（徒って説がいか強力であ、話がいかに

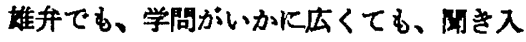
れられない)

なお(14)の “受”は「物を受けとる」といら 意味では睅予動詞たが、ここでは「説を受け

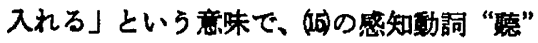
と似ている。

続いて『監銭諭』『論茼』を、漠代の調査 㾞料としてとりあげる。“見”の後につく娌 泀には、戦国中期以前・戦国末期にみられた 感知動詞・情热動詞・人事動詞の他、支配動 詞が多く出現している。

A. 抽象動詞 
A-1 惑知劺詞

“非（非難する）“拒”“妮”“略 告”“㯖（群を聴き入れる）"

A-2 你態動詞

“要”“佃”“噪（と中かくいら）

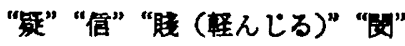

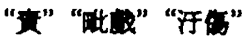

\section{B. 具体動詞}

\section{B-1 人素動詞}

“拘”“措”“塔”“客”“枉”“誅”

“殺”“坑(生き埋めにする)”“畔” “危”“報（報復する）“全（但害 する）“国”“砅”“官” “任”“代” “用（採用する）" “封”

\section{B-2 支配動詞}

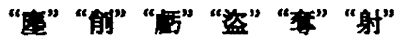
“學持”“探（採集する）”“吹呼 (息 を吹きかける＂［“從（意見飞従 5)”] [“屆（抑えこまれる）”

\section{B-3 賜予動詞}

“会享”“京” “歌”101

[“受（説を受け入れる）”]

C. 状然動詞

“息（なくなる）"

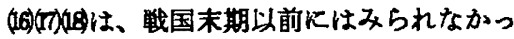

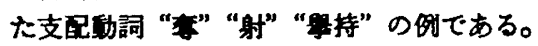
(16) 此段、周之所以失等，而見萦於锗侯也。

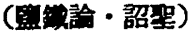

(それが、殷や周が貵力をらしない、諸侯 にらばわれた理由だ）

(IIt) 地火不爲見射而没，天火何営見射而去?

\section{（論衖・感虚）}

（地下の火が射られて消えないからには、 天の火がどらして射られてなくなろらか)

(18) 長数们之竹, 大㖶抱之木, 工技之人, 裁

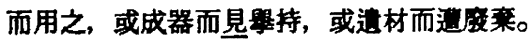

（諭衡・幸偶）

（長さ数仍の竹中、大きさ一抱えの木は、 職人が裁断して使えば、道具化なって大切
に报われることもあるし、不要な材料とし て乗てられることすある)

「“見”十動詞」の主語に目を向けると、(可 (18)では “地火 (地の火)” “天火(天の火)" “器 (道具)"とい5無䥼物か配されている。 無物を主語に取る例はこの3例たけけたが、 先莱文献にはみられなかった使われ方である。 (19)(20)賜予動詞 “荅亭”、状態動詞 “息” の例である。

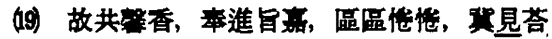
京。(旍衡・明等)

（ゆえに香りのよい物を供え、ごちそうを 捧げ、一生腎命心をこめて、受け入れられ ることを願 5)

(20) 故虚安之熺不黜，則華文不見息; (諭衡. 䍊作)

（虚妄の語が退けられなければ、華霞な文 が止められない)

(99)の “見荅京”の主語には「祭祀」をあら わす語が想定される。「祭祀」は、人の気持 ちに関係するのて、人に草ずるすのに分類で きなくるない。

以上、戦国中期加漠代までの「“見”+動 詞」の用例を時代順に観宗してきた。次節で はさらに用例全体にわたる分析を進め、被動 の “見” の变悬と特徽を考察する。

\section{3. “見”の特徽と变遷}

\section{1. 特改}

被動の “見” の用例を、後につく動詞およ び文全体から筧察していくと、時代を越えて 共通する特歓を三点举げることがでさる。第 一は、“見” の後につく勤詞の半数以上か、

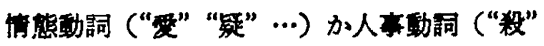
“任”…) であることである。第二牥、“見” の後につく動詞のあらわす動作行為・心理活 動か、受亭飞利益或い怯抶をむたらするの であることである。そして第三は、「“見”+ 動詞」の主語か、人或いは人に菹ずるすの （国・詩文・説・祭祀）には注限られること 
である。

第二・第三の特徽から「“見”十略詞」は、

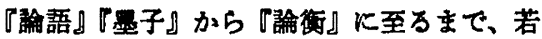
干の例外はあるものの、「人或いは人に草ず るものが利益或いは损失を䀞る」ことをあら わしているといえる。このことは、西田1964

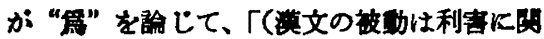
保があり、それは）被娌の主語が原則として 人格的なむの、つまり主体性のあるるの、有 伤的なるのであるとい5点からきている」と 指摘するのに合致する。“被”“為”を用いる 被動にも当てはまる、古漢語の本質的特徽と いえそ5である。

第一の特改、すなわち後につく䡃詞に倩隹

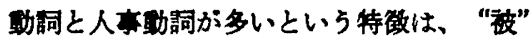
“鸴”との詳しい比校が必要ではあるが、“見” 特有のるのであると思われる。特に情热勤詞 の占める割合が多いことは、注目に值する。

\section{2. 変要}

以上のよらな本貿的特徽を有しながらす、 “見” Кは通時的な変化がられる。すなわ ち、戦国中期から莫代化かて、“見”の後 につく動詞の種類が増元、用例の延数も大幅 に增加しているのである。

動詞の種類は、先秦の調査資料では、感知 動詞 (“忘” “德”...) ・情態動詞 (“爱” “筷” …) ・人事動詞 (“般”“任”...) 飞注限られ るが、漠代になると、さらに支配動詞（“监”

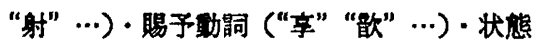
轵詞 (“息”) に属するるのが現れる”。

“見” の後につく㲜詞の種数が增加するK つれて、「“見”+㲜詞」の主語にも変化が生 してくる。「“見”+動詞」の主語は、先素・ 両漢を通して人或いは人に草な゙るもの（国. 特文·説·祭祀）に汪汪限られるが、時代が下 るにつれて、人に草ずるるのの揢合が増えて いく。具体的には、戦国中期以前では「“見” 十動詞」の主語は人と国だけだが、戦国末期 になると「説」をあらわす語 (“說”) が見れ、
璌代には「説」の伍か、「諭、眭文、祭祀」 をあらわす語 (“華文”“祭” ...) すみられる よ5になる。また東漢の『論䘖』には、僅か 3 例とはい方、無情物 (“地火” “天火” “器”) を主語にとる例むみられる。

用例の延数については、唐・周1985、唐19 87がより詳しい報告を行っている。それによ ると、戦国中期以前の『論語』『量子』『國吾』 『春秋左氏榎』ではいずれる 3 例满たなか った被動の「“見”+坋詞」の用例が、戦国後 期の『奋子』『倝非子』など 5 文献では合計 50例に增之、西漢の『史記』『說苑』など7 文献では106 例、東漢の『論得』『風俗通義』 など 5 文献では 113 例となっている12。

以上より「“見”+動跼」が、戡国中期から 漢代にかけて、活発な造句活動 (“見”字够を 造る活動)を行っている様子がらかがえる。

\section{3. 被野形式「“見”+動詞」の成立}

“見”の用例は、戦国中期まては、『論語』

1 例、『春秋左氏傮』3 例とい5よ5にごく 僅かである。この時期、「“見”十動詞」が、 被䡃の形式として成立していたとは考えにく い。

大野 1968 は、「(“見”は) 元来は被趿をあ らわするのではなく、本䄉基づいて、自己 に目することを見る、体倹する、…の目を見 ろ、…目にあふなどを意味するむのであ る」と述へろ。またそれは下の(2) (2)の“見” に近いことからす明らかであるとする。(21)

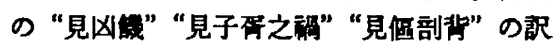
は、大野1968のとらえ方に従5。

(21) 民見凶僟則亡。（吐子・七患） （人民は凶作に远い亡びた）

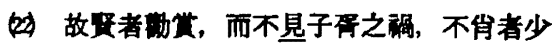
罪, 而不見愠剖背。（朝非子・用人） （故に才能・德行のある人は供に励まされ、 子甭が蒙ったような禍にはあわず、才能・ 徳行のない人る罪を犯すことが少なく、亚 が背中を㔊かれたよらな目とはあかない） 
旅勳の“見”が、「自己に関ナることを見

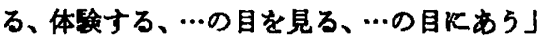

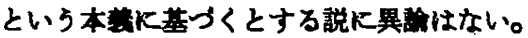
しかしょり基本的なところに立ち㞍ると、 “見”の本券は、「見る、感知する、出会ら、 …」である181。国中期までの「“見”十䡃詞」

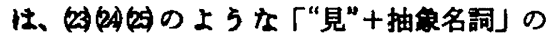
“見”などと同漛に、「見ろ、感知する、出 会ら、‥」といった本蓄で使われていたと思 われる。

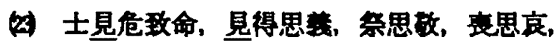
其可已矣。(詥語・子張)

（士は危険に迹えば命を投げ出し、利得を みれば晹を思い、祭には敬らことを思い、 衰には高しみを思ら、それでよいのだ）

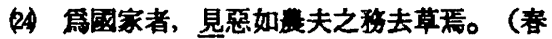
秋左氏傳・公 6 年)

（国家を治める者は、惠事を見たら、踝夫 が努力して雓草を取り除くようとしなけれ ぱならない)

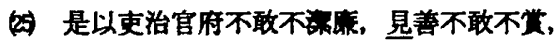
見暴不敢不叟。（量子・明鬼下）

（そこで役人が役所を治めるには清廉でな ければならず、着事を見ると栄を与克なけ ればならず、暴行があると周しなければな らない)

そらした中で、2節で管げた用例(9)佃の “見惡”“見伐”などが被動解されるのは、 第一飞“惡”“伐”などが主語に直接関わる 心理活動・動作行為・状紫变化をあらわして いるからであり、第二に 主語がそれらの心 理活動・功作行为・状䉥变化を、意図的火 「見る、感知する、出会5、…」のではなく、 非意四的化「見る、感知寸る、出会5、… からである。前者法、大野1968のい5「自己 と関わることを見る」К、後者は同しく「… の目を見る、…目にあら」К通しる。

国中期までの「“見”十野詞」は、それ自 体が被㲜の形式として啸立していたかけでは

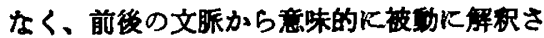

れていたと考えられる。

しかし笺国中期から莫代仂けて、「“見” 十勘詞」は馀↔K变化していく。動詞の程類 る、用例の延数す大幅譜之る。それはすな わち「“見”+野詞」が活発な造句活動を行い、 炊第に被就の形式として確立していったこと を物善っている。この時期「“見”十䖝詞」は、

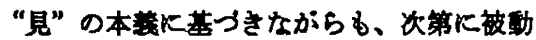
の形式としての意味・濑能を確立していった と推测される。

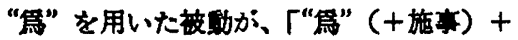
動詞」では造句活趿を行わず、「“第”+施事

+“所”十䦽詞」といら形式を得た後に大き く発展するのに対し14)、“見”を用いた被的 は、「“見”十别詞」のまま造句活動を行い、 徐々K被動の形式を成立させていったのであ $3^{151}$ 。

\section{4. まとめ}

本稿は、先秦・両漢の10文献飞みられる 「“見”十動詞」を、“見”の後住つく動詞化焦 点を当て調査・分析し、さらK文全体からの 覞察を加えた。結果は以下の通りである。

(1)先秦・両漠の「“見”十動詞」とは時代を越 えた特徵か三点みられる。第一K、“見” の後につく動詞は、半数以上が情態動詞か 人事野詞である16)。第二に、“見”の後に つく動詞のあらわす殾作行為・心理活较は、 受本に利益或いは損失をむたらするのであ る。そして第三に、「“見”十娌詞」の主語 は、僅かな例外を除き、人或いは人に草ず るむの（国・説・詩文・祭鞄）に汪注限ら れる。

第二、第三の特微から、先秦・两漠の「“見” 十動詞」は基本的に「人或いは人に寀ずる ののが利益或いは損害を被る」といら被動 羭を担っているといえる。 (2しかしなからら先秦・両漠の「“見”十動詞」 Кは通時的な変化もみられる。 
戦国中期から漠代にかけて、“見”の後に つく動詞の毢類が增え、用例の延数る大愊 飞增加するのである。戦国中期以前 - 戦国

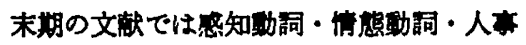
功同に属するるのに概ね限られるか，漠代 の文献になると、支配動詞・賜予動詞・状 热略詞に屈するるのる現れてくる。「“見”

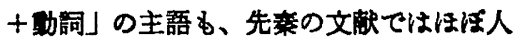
作られるが、漠代では人に菲ずるるの （国・説・時文・祭祀）が增え、東演の『論

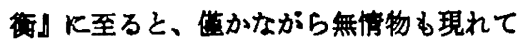
くる。

「“見”十加詞」は、戦国中期から漠代にか けて活発な造句活動を行い、徐々に被娌を あらわす形式を成立させていったと思われ る。

“見”の後につく動詞の種類が、漢代に大 きく増加していることは注目に值する。調查 対象とする文献を增やしての恰討が求められ る。殊に支配動詞・状態動詞をすつ用例が漢 代に出現したという現象については、時代を 確実に限定できる出土料の調査・分析す必 要であろら。

さらにその先の課題として、主動の “見” の胉查・分析が举げられる。西嫨以前の主功 の“見”之東漠・魏珰南北朝のそれとの成 保 ${ }^{17}$ 、東漠・魏晋南北朝の被䎣の “見”之同 時期の主功の “見” の成係などを、後につく 䡃詞を手がかりに探ってみたい゙1。

\section{〈注〉}

1）原文は “其息蓋謂 “不爲宰臣所哌”也， 則 '見哌' 二字反用矣, 未解” ( p.164)

2）呂1943はこの例を、被栜比も主勤にる解 粎できるとする。

3）「被動の変法」については杨1928でより 詳しく論しられている。

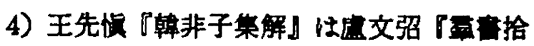

補』の校动を採用し、“皆見受”の前に“父
母”を補ら。ただし、慮文弨の根拠は必ず しも明かではない。

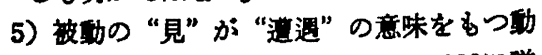
洞であるとする根拋は、姚1990、1999K詳 しい。

6）醜培泉1990は、王晖1986の挙げる先泰・ 両雚の用例は策わしいとする。さらに、仮 Кそれらを認めるとしても、主勳の“見” の用例が被副の“見”に比ぺて少なすぎる のは何故か、とい5寲問を呈している。し かし施受同辞の用例が一方片寄ることは 珍しくない。たとえば、使動用法をるつ語 は施受同辟であると考えられるが、一般用 法と使勤用法の用例数が大きく異なる例は よくある。具体的には本1983、小方1998を 参照されたい。

7）大野1968. p.90。

8）魏培泉1994Kよると、被禹の意味をあら

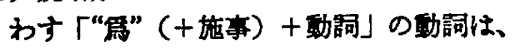

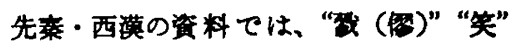
“用”“推 (偊)”“役”“使”が八、九割を 占める。

9）対象とする资料隹用例のない㖽目は外す。

10）“京”“歌”の使用例は次の文である。

見旰, 若祭不見享之䙐; 多助, 若祭見歌之 楅。(論衡・施啭)

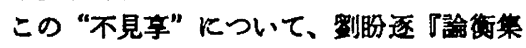
解』は“不見享”當是“見不享”之注して いる。それに徙らと、“見不豙之裸”は「受 け入れられない福にあ5」、“見歌之福”は、 「受け入れられる福にあら」と解然され、 “見”は被動をあらわするのではなくなる。

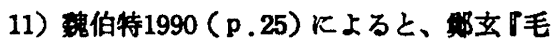
詩渡嘎』、何休『春秋公羊解話』、趙岐『孟 子苦句』にみられる“見”字句の轩詞は103 程類に及心゙。例として“传”“侵容”“传邻” “位伐”“依侮”が举げてある。

12）文献によっては、策者の調㚗結果と奥な ろるのもある。たとえば『春秋左氏信』の 用例数は唐・周1985では 1 例、等者の解查 
では3 例である。「“見”十野詷」は主害が 省略されることが多く、被偊と主䡃の差が 眣な例が少なくない。そのため魏培泉19 90は、唐・周1985、唐1987の調査結果を疑 わいいとする。それは礁加不定できない が、括およその傾向はつかめると思5。

13）『說文解字（8下）』は“見”を“梘也” と解する。“見”と“視” の相速比ついて 王风阳1993は、『碽記・大學』の “心不在

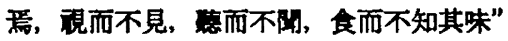
を引き、「“視”は主覞的に見ることである。 目にはいることる、はいらないことるある。 “見” は客覞的に事物が視场にはいること である。主得的には、意識してみる场合る、 繁意識にみる場合るある。ただし実祭には、 目にはいっている」とする (p.735)。

14）魏培泉1994, pp. 304-306。

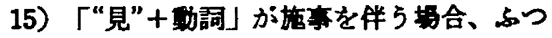
5 “於”を用い、しかる語順は必ず “見” の後になる。これは“臨”“被”などを用 いた被䖝表現との決定的な差巽である。 「“見”+動詞 (+“於”+施索)」の変退を詥 じろ上での重要な視点のひとつであろう。

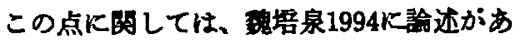
る。ただし本稿では、「“見”+動詞(十“於” 十施事)」をひとつの枠組とし、後化つく 動詞からその変至と特徽をさぐるといら方 法をとり、「“見”十動詞」と「“見”十䡃詞 十“於”十施事」の差異には立ち入っていな w。

16)六朝の『世說新語』では、被動の “見” の後にくる動詞は情隹劧詞と人事動詞に限 られる。

17）先秦・両漠のいわゆる主野の “見” の用 例は、本文で报った10文献全体でる10数例 しか見当たらない。一人称代絽の意味・機 能をすつすのに偏るといらこともなく、一 般動詞「示す」とみて差し支えないるのば かりである。以下にそのうちの 3 例を器げ る。
上下見网而強見也。（茫子・天下）

烈士営天下見善㚐，末足以活身。（荘子. 至樂)

今昭公見惡䖽罪而不誅。（韩非子・難四）

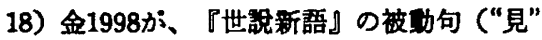
字句、“被” 字句、“烝” 字句…) の用例を 周査し、主語にとって姲しいこと或いは幸 せなととをあらわしているか石かの珫計を とっている。それKよると見字句は、主語 にとって婹しいこと或いは幸せなことをあ らわしているすのが 9 例、姑しくないこと 或いは不幸なことをあらわしているすのが 7 例みられる。

\section{〈テキスト〉}

『論語集擇』程樹徳，新編諸子集成(第一舴)， 中華害局1990

『量子校注』吳解江，新稨諸子集成(第一輯)， 中華害局1993

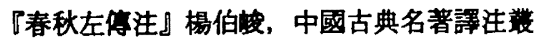
毒, 中華害局1990

『荘子集解』郭度藩，新編諸子集成(第一栮)， 中華書局1997

『孟子正教』焦循, 新編諸子集成(第一輯), 中華害局1987

『苟子集解』王先潇，新編諸子集成(第一栮)， 中華書局1988

『暲非子集解』王先伿，新編諸子集成（第一 评)，中華害局1998

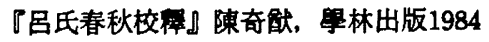

『箩鐵論校注』王利器，新編諸子集成（第一 埾), 中華害局1992

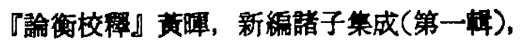
中華意局1990

\section{〈察引〉}

『論語逐字索引』商務印毒馆1996

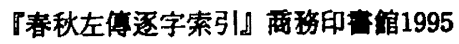

『孟子逐字索引』票弱印管馆1995

『苗子逐字索引』商務印害馆1996 
『呂氏春秋逐字索引』满移印素馆1994

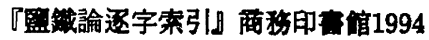

以上、「先秦兩漠古籍通字索引粼刊（香港 中文大学中國文化研究所)」

『星子引得』引得編算虑，上海古籍出版1986 『庄子引得』引得編算虑，上海古籍出版1986 『畭非子索引』周等主編，中華意局1982 『鮽俩索引』程湘清等主編，中華害局1994

\section{〈参考文部〉}

金大焕 1998. 「试折〈世说新语〉 中的被动句 式」『中国学研究』第二辑，pp.237-284。 刘瑞明 1995. 「从泛义动词讨论“见” 字本不 表示被动一一莱放动句有关问题」『湖北 大学学报』1994-5/(再录)1995『复印报刊 料语言文字学』1995-1, pp.74-81。 本佐丰 1983.「先采汉语的自动词及便动用法」

『语言学论从日第10辑, pp.117-144。 社。 1994 . 『文言实词』。北京：语文出版

吕叔湘 1943. 「见字之指代作用」(再录) 1955

『汉语语法论文集』pp.46-50。

马建忠 1898。『马氏文通』/(再版) 1983 「汉 语语法丛书」。北京：商务印书馆。 西田太一郎 1964. 「漢文の被動飞ついて」『東 方学』第27辍, pp. 103-108。 大野透 1968. 『漢文法の遡源的研究 1 do 東 京: 松雲堂書店。 小方伴子 1998.『論衡』の使動用法」『中国 蓓学』245号, pp. 11-20。

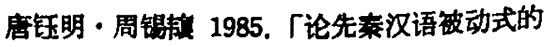
发展」『中国语文』1985-4, pp. 281-285。 唐钔明 1987. 「汉魏六朝被动式略论」『中国 语文』 1987-3, pp. 216-222。

王风阳 1993.『古辞』吉林文史出版社。

王晖 1986. 「同形结构中的 “见” 字为施受 同辟说」『汉中师范学报』1986-1/(再录) 1986『复印报刊资料语言文字学』1986-11, pp. $93-100$ 。

魏伯特 1990.「邲玄，趙歧，何休停等的一些 語法特色」國立要湍大學碩士諭文。

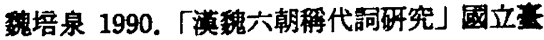
灣大學博士論文。 1994. 「古漠語被動式的展與演紧機 制」『中國境內語言暂語言學』第二輯，pp. 293-319。

杨树达 1924. 『古书锤义举例续补』家刻版。 /(再录) 1984 『古书字义用法坐刊』。北 京 : 北京市中国书店。 1928.『词垥』/(再版) 1986。上海： 上海古籍出版社。 1931. 「马氏文通刊误』/(再版) 1962。 北京：中华书局。 姚振武 1988. 「古汉语 “见 V” 结构再研究」

『中国语文』1988-2, pp. 134-142。 1990. 「古汉语受事句 “见V” 中结构 再研究」『古汉语研究』1990-2, pp. 35-39。 1999. 「先蒌汉语受事主语句系统」

『中国语文』1999-1, pp.43-53。 